\title{
Literature analysis on product-service systems business model: a promising research field
}

\author{
Suzana Regina Moro ${ }^{1}$ (D), Paulo Augusto Cauchick-Miguel² (D), Glauco Henrique de Sousa Mendes (D) $^{2}$ \\ ${ }^{1}$ Federal University of Santa Catarina - UFSC, Graduate Program in Production Engineering, Florianópolis, SC, Brazil. \\ ${ }^{2}$ Federal University of Santa Catarina - UFSC, Production Engineering Department, Florianópolis, SC, Brazil. \\ ${ }^{3}$ Federal University of São Carlos - UFSCar, Production Engineering Department, São Carlos, SP, Brazil.
}

How to cite: Moro, S.R., Cauchick-Miguel, P.A. and Mendes, G.H.S. (2022), “Literature analysis on product-service systems business model: a promising research field", Brazilian Journal of Operations \& Production Management, Vol. 19, No. 1, e20221220. https://doi.org/10.14488/BJOPM.2021.043

\begin{abstract}
Goal: Product-service system (PSS) is a business model implemented by organizations aiming at generating profitability and competitiveness, and contributing to sustainability. However, companies need to build up new skills to develop and implement PSS focused on business models that should be able to generate value. This context calls for a theoretical analysis with the objective of identifing characteristics of this type of business model by means of a literature review.
\end{abstract}

Design / Methodology / Approach: A descriptive review was conducted, and 313 publications related to PSS business model were selected. A final set of 48 articles related to PSS and business models were identified as well as the number of publications per year and main journal. Mechanisms for generating value from the PSS business model and its components were described after content analysis.

Results: Most of PSS business model publications were published in recent years with the main focus on sustainability. Fourteen business model components were identified from the literature to be considered when structuring a PSS, associated with value proposition, creation, delivery, and value capture mechanisms. The most common components were 'value proposition' and 'key partners', although their concepts need a clarification. The business model should be designed with a valuecentric vision in an iterative process. Moreover, it must cover the interests of the entire PSS value network, considering environmental, economic, and social dimensions of sustainability.

Limitations of the investigation: The analysis has not considered the related research field on servitization, and nor the publications related to the 'value' concept from interdisciplinary areas (e.g., marketing).

Practical implications: Developing a PSS business model requires forming a value network, considering the interests and responsibilities of those involved for the generation of mutual value as well as the inter-organizational relationships.

Originality / Value: As PSS as a business model is a promising field of study, this paper devotes more attention on developing this kind of business model.

Keywords: Product-Service System; Sustainable Business Model; PSS Value Generation; Literature Review.

\section{INTRODUCTION}

In response to several transformations that have been taking place over the years, such as extensive globalization, increased competition based on low costs, and networks guided by

Financial support: Coordination for the Improvement of Higher Level Education Personnel (CAPES) and National Council for Scientific and Technological Development (CNPq) - doctorate grant [140460/2016-0] and financial support [428946/2018-6].

Conflict of interest: The authors have no conflict of interest to declare.

Corresponding author: suzana.moro19@gmail.com

Received: 19 Apr 2021.

Approved: 6 July 2021.

Editor: Julio Vieira Neto. 
demand (Van Halen et al., 2005), companies increasingly realize the need to readjust their strategies, focusing in generate value for customers (França et al., 2017). For example, the automotive industry, traditionally based on vehicle sales, has been investing on new ways of offering mobility, concentrating on providing value to the customers in the product use phase (Mahut et al., 2017). An example is a recent initiative from VW Brazil to offer a subscription vehicle service, with the possibility of contracting online (Volkswagen, 2021). When hiring the "VW Sign \& Drive", the customer finds out a transparent pricing proposal (minimum period of one year), which includes taxes and duties, insurance, and preventive maintenance (Monteiro, 2020). This business model example changes the way customers perceive the culture of vehicle ownership and disbursement of money and requires a reorganization of the value chain (Estigarribia, 2020). Nonetheless, the transition from product to performance-focused based on product-service integration requires developing innovative business models (Evans et al., 2017).

An approach based on product-service system (PSS) focuses on new business models that meet the customer's functional needs innovatively by adding services to the products offered (Scheepens et al., 2016). This approach was proposed as an opportunity to promote the sustainability and strategic development of the business model (Tukker, 2004; França et al., 2017), as a solution to deliver value to customers (Reim et al., 2015). Bike-sharing system is an example of PSS offered as a sustainable alternative (Sousa-Zomer et al., 2016). Additionally, product-service offers could also contribute to increasing organizations' differentiation against competitors and increase in profit margin (Annarelli et al., 2016; Mahut et al., 2017).

With the promise of increasing attractiveness to customers, new PSS business models should provide some environmental benefits and make PSS viable as opposed to traditional production/consumption business models (Pialot et al., 2017). Besides the mobility sector previously cited, PSS have been offered by companies from different sectors such as lighting system, printers and photocopiers, water purifiers and material handling operations (Beuren et al., 2013; Brambila-Macias et al., 2018; Sousa-Zomer et al., 2018). To deliver these product-service offers, an innovative business model should be developed, supported by the concept of sustainability (Bocken et al., 2014). Developing a PSS or transforming an existing business model into PSS has been described as a business model innovation for sustainability (Evans et al., 2017).

Although PSS as a research topic emerged during the 90 s, it continues to attract interest, with a steadfast growth of publications, possibly due to the convergence of specific causes over the years, such as communication and information technology and its wider adoption by industrial organizations (Annarelli et al., 2016). Nevertheless, many companies have faced difficulties developing their business model as a PSS (Reim et al., 2015) and combining sustainability with innovation (França et al., 2017). Considering that business model is a promising field of study, the investigation on concepts of business models applied specifically to a PSS deserves attention and could be interesting to provide a better understanding of PSS not only for researchers but also PSS developers.

In this sense, this investigation aims to analyze the literature on PSS from a business model perspective, aiming to identify how publications have addressed this concept and the required components for companies to develop their PSS business model focusing on value generation. The following section points out some concepts related to the business model. Later on, the research methodological procedures adopted to conduct this literature review are described. The results of literature analysis related to the PSS business model included quantitative results of the publications, as well as the analysis of the components and mechanisms for generating value from the business model. To finish, concluding remarks, as well as the limitations of this work and future research opportunities are posed. 


\section{BUSINESS MODEL RELATED CONCEPTS}

A business model is a conceptual representation that helps to link an organization's strategy to its activities (Richardson, 2008). The business model concept spread exponentially after a work co-created by 470 practitioners from 45 countries (Osterwalder and Pigneur, 2010), elaborated mainly based on Osterwalder (2004), which addresses the ontology of the business model. The author defines the term 'business model' as (Osterwalder, 2004, p.14): "a representation of how a company buys and sells goods and services and makes money." The business model connects technical potential with economic value realization (Chesbrough and Rosenbloom, 2002). Concerning the operational dimension, the 'business model' concept essence was already presented by Peter Drucker in the 50s, which is a classic source for business studies (Fjeldstad and Snow, 2018). The works of Chesbrough and Rosenbloom (2002), Osterwalder et al. (2005), as well as Teece (2010) offer theoretical contributions to business model subject. However, there is still a lack of clarity, conceptual consensus, and consistency in the use of the terms business model, business model innovation, and sustainable business models (Osterwalder et al., 2005; Boons and Lüdeke-Freund, 2013; Evans et al., 2017).

While it is possible to design generic business models, each company has its unique business model, which describes how the company creates and captures value (Kindström and Kowalkowski, 2014). According to this perspective, each company must structure its business model individually to suit its strategy and operations (Tukker, 2015).

Changing a business model constitutes an innovation process in the current scenario of business models (Kindström and Kowalkowski, 2014; Fjeldstad and Snow, 2018). Unlike product or service innovation, business model innovation does not necessarily discover a new product or service, but it uses new ways to create and deliver the existing product or service and new ways to capture its value (Yang et al., 2017). A business model development consists of structuring several components (also called by the literature as elements, functions, or attributes of the business model) described next.

\section{Business models components}

Generally, a simplified representation of the elements that make up the system, as well as the interrelationships between these components is used (Geissdoerfer et al., 2018). After the business model components analysis and contrast from the perspective of several authors, Osterwalder (2004) describes nine components that cover four primary areas of a business, namely: (i) customers, (ii) supply, (iii) infrastructure, and (iv) financial viability. Osterwalder and Pigneur (2010) developed structured components by a framework - Business Model Canvas (BMC), which are illustrated in Figure 1.

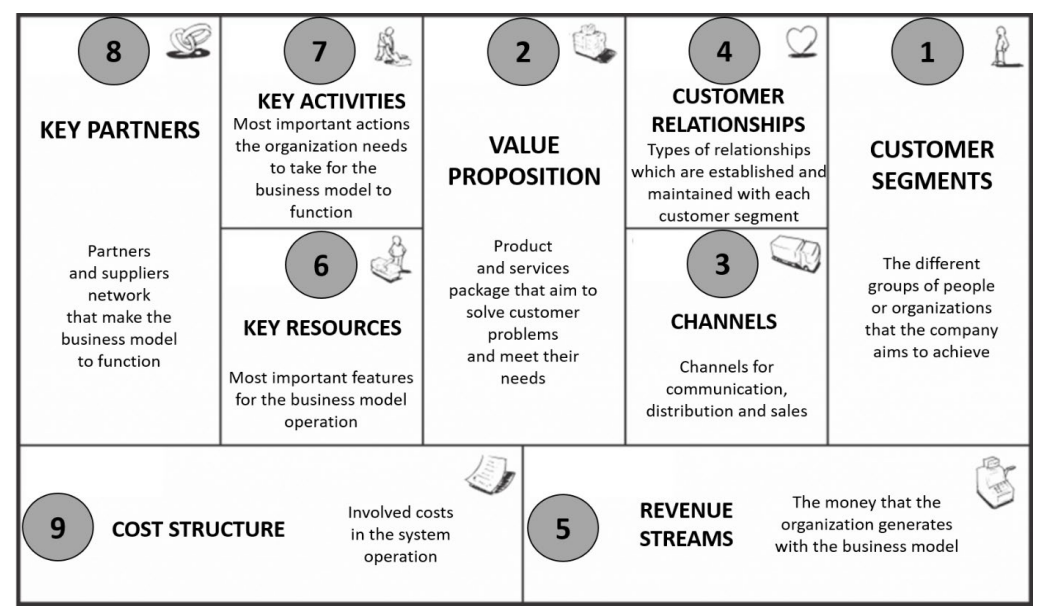

Figure 1. Business model components (adapted from Osterwalder and Pigneur, 2010). Note: the changes added sequential numbering and a brief description of each of the components. 
The business model components showed in Figure 1 are interdependent. For instance, the channels used for communication depend on the customer segment that the company wants to achieve. As a consequence, one component's change depends on the corresponding changes and other components' realignment for successful innovation (Kindström and Kowalkowski, 2014).

\section{Sustainable business model}

The literature on business models shows that PSS is a sustainable way to offer value to customers (Boons and Lüdeke-Freund, 2013; Bocken et al., 2014). In its origin, PSS, focused on sustainability issues. After the concept evolution, the business model's profitability and companies' competitiveness became central issues. In addition, PSS should combine the three sustainability dimensions (economic, environmental, and social) in a holistic approach, meet the customer needs (Vasantha et al., 2012), and focus on value generation. Table 1 summarizes the sources of value related to sustainability dimensions.

Table 1. Sustainable values and sources.

\begin{tabular}{|c|c|}
\hline Sustainability dimensions & Value sources \\
\hline \multirow{5}{*}{ Economic } & Business stability \\
\hline & Financial resilience \\
\hline & Long-term viability \\
\hline & Profit \\
\hline & Return on investment \\
\hline \multirow{5}{*}{ Environmental } & Biodiversity \\
\hline & Little waste \\
\hline & Low emissions \\
\hline & Pollution prevention \\
\hline & Renewable resources \\
\hline \multirow{6}{*}{ Social } & Community development \\
\hline & Equality and diversity \\
\hline & Health and safety \\
\hline & Labour patterns \\
\hline & Safe living \\
\hline & Welfare \\
\hline
\end{tabular}

Source: Evans et al. (2017).

When considering business model innovations for sustainability, there is a greater complexity associated with assessing the impact of sustainability innovations and understanding their effects across the business network (Evans et al., 2017). A sustainable business model's fundamental idea is a sustainable value proposition, which allows the simultaneous creation of value for multiple stakeholders, including customers, shareholders, suppliers, partners, the environment, and society (Bocken et al., 2014). In most business models, the basic principles are related to the value concept (Evans et al., 2017; Yang et al., 2017). It determines the value proposition, the creation and delivery of value, and the capture of value (Geissdoerfer et al., 2018). Bocken et al. (2014) and Short et al. (2014) defined these value-related concepts according to the sustainability perspective, as described in Table 2 . 
Table 2. Business model value-related concepts.

\begin{tabular}{|c|c|c|}
\hline Value-related concept & Description & References \\
\hline Value proposition & $\begin{array}{c}\text { It refers to describing the business model's value } \\
\text { purpose to customers, differentiating them from } \\
\text { competitors, and sustaining the activities and } \\
\text { resources }\end{array}$ & $\begin{array}{l}\text { Bocken et al. } \\
\qquad(2014)\end{array}$ \\
\hline $\begin{array}{l}\text { Value creation and } \\
\text { delivery }\end{array}$ & $\begin{array}{l}\text { It refers to how value is provided to customers. In the } \\
\text { case of a PSS, significant changes are required in the } \\
\text { company, with incentives from the design for } \\
\text { durability, reparability, and facilitating the update }\end{array}$ & $\begin{array}{l}\text { Bocken et al. } \\
\text { (2014), Short et al. } \\
\text { (2014) }\end{array}$ \\
\hline Value capture & $\begin{array}{l}\text { It refers to how the company makes money and } \\
\text { captures other forms of value }\end{array}$ & $\begin{array}{c}\text { Teece (2010), } \\
\text { Bocken et al. } \\
\text { (2014), Short et al. } \\
\text { (2014) }\end{array}$ \\
\hline
\end{tabular}

After establishing the basis of this work, the following section describes the methodological research approach.

\section{RESEARCH METHODS AND PROCEDURES}

The research question that guides this literature review is: "how PSS as a business model has been described in the literature?". The research methods and procedures to conduct this literature review were developed based on the recommendations from King and He (2005); Booth et al. (2012); and Adams et al. (2017) to conduct 'descriptive reviews'. This type of literature review generally involves a systematic search of as many as possible relevant papers in an investigated area to represent the state of a research domain (King and He, 2005).

The search was done at Scopus, ISI Web of Science and Compendex (Engineering Village) databases, which are considered the main bases covering multidisciplinary subjects (Booth et al., 2012) as well as engineering. Table 3 summarizes the research procedures for search and selection of publications (based on Booth et al. 2012).

Table 3. Methodological procedures for searching and selecting publications.

\begin{tabular}{|c|c|c|}
\hline & Procedures & Description \\
\hline \multirow{13}{*}{ 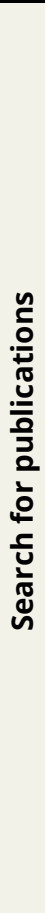 } & Purpose & $\begin{array}{c}\text { PSS business models conception, description of the PSS } \\
\text { business models components, and PSS value addition } \\
\text { mechanisms }\end{array}$ \\
\hline & \multirow{3}{*}{ Keywords } & Searched in title, keywords, and summary of publications: \\
\hline & & $\begin{array}{l}\text { Axis } 1 \text { - PSS: "product-service system*" OR "product- } \\
\text { extension service*" OR "integrated product-service*" OR } \\
\text { "product-service offer*" }\end{array}$ \\
\hline & & Axis 2 - Business model: "business model ${ }^{\star "}$ \\
\hline & Databases & $\begin{array}{l}\text { Scopus, ISI Web of Science and Compendex } \\
\text { (Engineering Village) }\end{array}$ \\
\hline & Search period & $\begin{array}{l}\text { Searches carried out between April and July } 2018 \text { - no } \\
\text { date filter was used for publications }\end{array}$ \\
\hline & Selected publication types & Articles published in peer-reviewed journals in English \\
\hline & \multirow{4}{*}{ Obtained number of publications } & 371 publications \\
\hline & & Scopus: 122 \\
\hline & & ISI Web of Science: 113 \\
\hline & & Compendex - Engineering Village: 136 \\
\hline & Update (after the first analysis) & 93 publications (3 databases) from 2018-2019 \\
\hline & Total - set of articles & 313 publications \\
\hline
\end{tabular}


Literature analysis on product-service systems business model: a promising research field

Table 3. Continued...

\begin{tabular}{|c|c|c|}
\hline & Procedures & Description \\
\hline \multirow{6}{*}{ 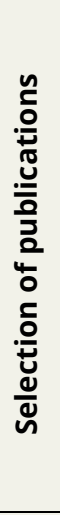 } & Total non-duplicates & 220 publications \\
\hline & Criteria for selection & $\begin{array}{l}\text { Publication selected conceptualize and describe } \\
\text { business models and their components }\end{array}$ \\
\hline & Reference management software & Endnote $^{\mathrm{TM}}$ \\
\hline & $\begin{array}{c}\text { Reading the title, keywords, and } \\
\text { summary }\end{array}$ & 74 publications \\
\hline & Full reading & 36 publications \\
\hline & Retrospective procedure & $\begin{array}{c}\text { Analysis of references cited by the selected publications } \\
\text { - inclusion of } 29 \text { publications (books and technical } \\
\text { publications on business model cited by the selected } \\
\text { articles were also considered) }\end{array}$ \\
\hline \multirow{8}{*}{ 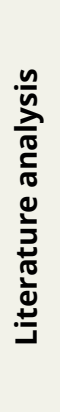 } & Data analysis Software & Endnote $^{\mathrm{TM}}$ and Microsoft Excel ${ }^{\mathrm{TM}}$ \\
\hline & \multirow{4}{*}{ Total publications analyzed } & 65 publications \\
\hline & & Business model: 13 \\
\hline & & Sustainable business model: 9 \\
\hline & & PSS business model: 43 \\
\hline & \multirow{2}{*}{$\begin{array}{l}\text { Publications included in the } \\
\text { analysis (2018-2019) }\end{array}$} & 11 - PSS business model \\
\hline & & 1 - sustainable business model \\
\hline & PSS business model components & 18 publications analyzed \\
\hline
\end{tabular}

A total of 313 non-duplicated peer-reviewed publications related to PSS and business model were considered for further selection. Quantitative information regarding these publications - such as year of publications and top-published journals - is provided as a general view of the research topic.

After the selection of the publications, an analysis of the reference list was conducted by applying a retrospective procedure. This consists of searching for studies cited by the analyzed publications (Gough et al., 2012), since most of the studies use the term 'business model', but do not describe its components (Figure 1). Because this work also aimed at understanding the concept of the PSS business model and its components, gray literature publications - 'first layer' - were also considered when applying the respective procedure, to fill in gaps in the academic literature as recommended elsewhere (Adams et al., 2017). Previously cited authors add that the 'first layer' is the clearest gray literature in terms of controlling the transparency of the source with significant credibility (e.g., book chapters, and government reports). Books published by authors with prominence in the subject (e.g., Osterwalder and Pigneur, 2010, Osterwalder et al., 2015) were also taken into account. Thus, this literature review embraced the analysis of 65 publications related to PSS business models.

Based on the analysis of the selected publications that presented the business model components (18 publications), a comparison among the components depicted by them was carried out. The components considered when structuring a PSS business model were highlighted by means of content analysis (as in Seuring and Gold, 2012). Finally, PSS business models' value addition mechanisms were described in terms of value proposition, creation, delivery, and value capture (discussed by 43 publications), and a summary of the components and mechanisms for generating value to the PSS were developed. Afterwards, an updated was performed to provide a recent perspective of publications in PSS business model topic, by including some other sources in the analysis (e.g., Oliveira et al., 2018; Kwon et al., 2019). A final set of 48 articles related to PSS and business models were then analyzed. 


\section{RESULTS OF LITERATURE ANALYSIS}

The PSS business model subject is relatively recent in literature. Figure 2 shows the distribution of papers along the time. More than half (56\%) of the 313 publications selected are from 2017 onwards.

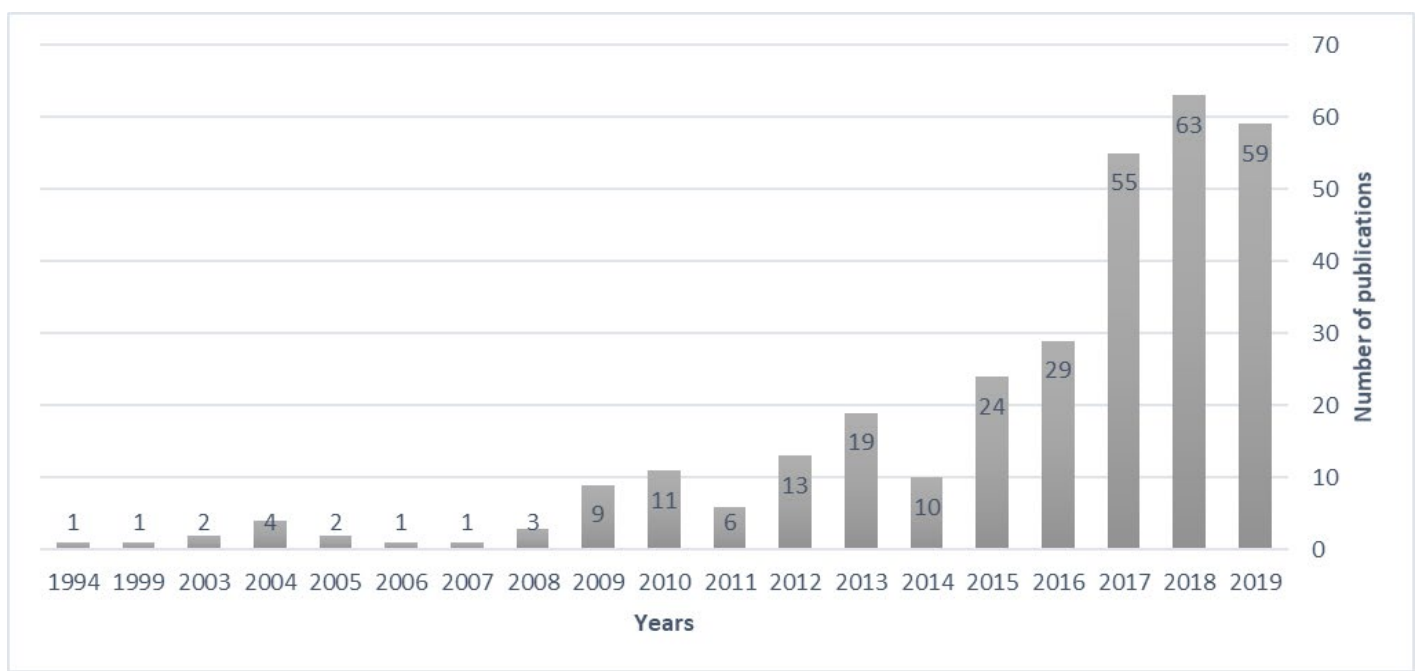

Figure 2. Distribution of publications per year $(n=313)$. Note: articles published in peer-reviewed journals in English

These articles were published in 121 journal sources. Figure 3 shows the top-published journals $(n>3)$ of the publications about PSS business models. These 15 journals sources are responsible for more than half (58\%) of the total of publications.

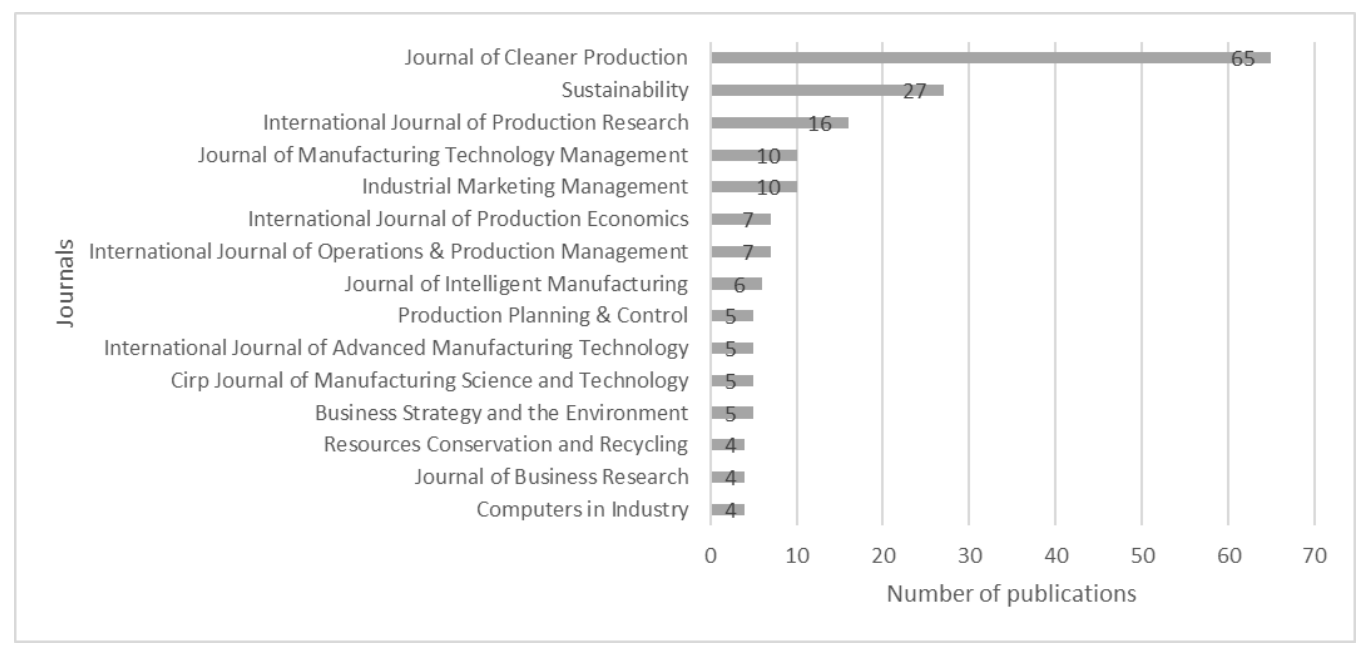

Figure 3. Top-published journals $(n>3)$ of publications $(n=313)$.

As somewhat expected, sustainability-related journals are the most common sources for PSS business model publications. Journal of Cleaner Production stands out as the main journal with publications on the subject. Since 2017, interest in the topic has grown in production management journals (International Journal of Production Research, International Journal of Production Economics, and International Journal of Operations \& Production Management), and marketing journals (Industrial Marketing Management and Journal of Business \& Industrial Marketing). Next section presents the results of the content analysis concerning business model components and mechanisms for generating value from the PSS business model. 


\section{Mechanisms for generating value from the PSS business model}

Pawar et al. (2009) identified the following steps for value creation in product-service offerings:

(i) Defining value - identifying the customer's value, needs, and cost of meeting them to determine the profitability of a PSS;

(ii) Designing value - identifying organizational requirements in terms of resources and capabilities that are available or needed; and

(iii) Delivering value - selecting the partners' network to provide the necessary resources and manage that network's performance to ensure uninterrupted access to value for customers.

Evans et al. (2017) point out that the internalization of externalities through the PSS (e.g., maintenance, repair, etc.) enables innovations for sustainable business models. The externalities of product-based business models are brought to the core of the PSS concept. Evans et al. (2017) add that to internalize them, it is essential to incorporate life cycle thinking concepts and establish new ownership modes that lead companies to greater responsibilities.

It is a consensus among the main authors that the 'value proposition' is the key component of business models (Adrodegari et al., 2017). However, the value proposition is difficult when developing a business model. Charro and Schaefer (2018) used the BMC structure and the value proposition framework of Osterwalder et al. (2015), which focused specifically on developing a business model's value proposition. In this sense, the cited authors add that it is necessary to understand the customer tasks (or 'customer jobs') to develop the PSS value proposition. Additionally, the value proposition must communicate potentially favorable changes in value to the client, such as reduced problems/pains and benefits/gains (Osterwalder et al., 2015). So, it must be clear the benefit/value that customers receive (Adrodegari et al., 2017). Moreover, customer problem-solving must incorporate the three dimensions of sustainability (Clark et al., 2009, Parida et al., 2014). Therefore, to develop the value proposition, strategies can be used that integrate economic, environmental, and social issues, focusing on value exchange.

The PSS business model's value creation is responsible for defining the main characteristics and quality of the PSS (Annarelli et al., 2016). The business model's improvements should not limited be to the company's production areas and all product and supply value chain activities, but they can emerge at any point along the PSS life cycle (Van Halen et al., 2005).

The PSS value delivery mechanisms comprise the description of distribution channels, customer relationships, and process efficiency. It is necessary to identify concerned parties in business relationships and develop close collaboration between the customer and the supplier through interactive procedures (Vasantha et al., 2012). In this case, more cohesive joined-up thinking and reconfiguration of various aspects of the business, such as capabilities, relationships with stakeholders, knowledge management, leadership, and culture are required, therefore involving the entire business model (Evans et al., 2017).

Value capture refers to mechanisms associated with the final results of the business model, such as those associated with the cost structure and revenue streams. However, the literature points out that, in practice, PSS providers have struggled to fully capture PSS offerings' benefits (Yang et al., 2017). Another vital factor to consider is that sustainable business models require a value network with a new purpose, design, and governance, considering stakeholders' interests and responsibilities in creating mutual value (Evans et al., 2017). After analyzing these PSS business model concepts, the next section provides a summary of the analyzed product-service system components and mechanisms to value generation.

\section{PSS business models components analysis}

A PSS involves a change in the product-service mix, moving from a 'resource-based' production system to a 'knowledge-based' system in which business activities aim to meet 
customer needs (Van Halen et al., 2005). Therefore, the developed PSS business models must consider adding extra value to solutions, which mainly concern meeting customer needs with a competitive cost (Scheepens et al., 2016).

Adopting the business model approach provides a more comprehensive understanding for companies to successfully leverage, coordinate, and align the transformations required for operationalization (Adrodegari et al., 2017). This opens an opportunity for business model offers to close the gap between knowledge about the effects of individual variables on company performance and the need for learning about how relationships between these variables affect performance (Fjeldstad and Snow, 2018).

The Business Model Canvas (BMC) proposed by Osterwalder and Pigneur (2010) is often cited and may be considered as a standard support for the business model design since it was developed through extensive research and represented the consensus of a large group of experts from academia and industry (Barquet et al., 2013). BMC by Osterwalder and Pigneur (2010) was proposed for the development of internet-based business model innovations. The proposed structure is one of the most recognized in the literature (Oliveira et al. 2018). A number of publications used the BMC structure to examine business models, e.g., Barquet et al. (2013), França et al. (2017), Gembarski and Lachmayer (2017), Pallaro et al. (2017), Charro and Schaefer (2018), Oliveira et al. (2018), Kwon et al. (2019), Majava and Isoherranen (2019), to name but a few. Barquet et al. (2013) argue that BMC structure stands out as an appropriate tool; it was developed through extensive business model research, and represents the consensus of a large group of academics and industry experts. SousaZomer et al. (2018) and Sousa-Zomer and Cauchick-Miguel (2019) used Bocken and Short (2016) structure to describe sustainable PSS. Table 4 highlights the publications that presented business model components.

Table 4. Contributions of business models from the literature.

\begin{tabular}{|c|c|c|c|c|}
\hline Publication & Main focus & Brief description & $\begin{array}{l}\text { Depth of } \\
\text { contents }\end{array}$ & $\begin{array}{c}\text { \# of } \\
\text { components }\end{array}$ \\
\hline \multirow{2}{*}{$\begin{array}{l}\text { Osterwalder and } \\
\text { Pigneur (2010) }\end{array}$} & \multirow{2}{*}{$\begin{array}{c}\text { Business } \\
\text { model } \\
\text { innovation }\end{array}$} & \multirow{2}{*}{$\begin{array}{l}\text { It explains the most common } \\
\text { business model standards based } \\
\text { on business concepts }\end{array}$} & \multirow[b]{2}{*}{ Detailed } & 9 \\
\hline & & & & (see Figure 1) \\
\hline $\begin{array}{l}\text { Meier et al. (2010); } \\
\text { Meier et al. (2011) }\end{array}$ & IPSS & $\begin{array}{c}\text { It describes the modular } \\
\text { organization and the actors' } \\
\text { network involved }\end{array}$ & General & 4 \\
\hline $\begin{array}{l}\text { Boons and } \\
\text { Lüdeke-Freund } \\
\text { (2013) }\end{array}$ & $\begin{array}{l}\text { Sustainable } \\
\text { business } \\
\text { models }\end{array}$ & $\begin{array}{l}\text { It proposes examples of } \\
\text { regulatory requirements that } \\
\text { business models must meet to } \\
\text { support sustainable innovations }\end{array}$ & General & 4 \\
\hline $\begin{array}{l}\text { Bocken et al. } \\
\qquad(2014)\end{array}$ & $\begin{array}{l}\text { Sustainable } \\
\text { business } \\
\text { models }\end{array}$ & $\begin{array}{c}\text { It incorporates the Triple } \\
\text { Bottom-line (TBL), considering } \\
\text { concerned parties, including } \\
\text { environment and society, } \\
\text { considering value-related } \\
\text { mechanisms }\end{array}$ & $\begin{array}{l}\text { Detailed ( } 2 \\
\text { levels) }\end{array}$ & $10^{*}$ \\
\hline $\begin{array}{l}\text { Gaiardelli et al. } \\
\qquad(2014)\end{array}$ & Green PSS & $\begin{array}{l}\text { It develops a model for } \\
\text { classifying traditional and green } \\
\text { product and service offerings, } \\
\text { pointing the elements of a PSS }\end{array}$ & General & 4 \\
\hline $\begin{array}{l}\text { Kindström and } \\
\text { Kowalkowski } \\
\text { (2014) }\end{array}$ & $\begin{array}{c}\text { Service } \\
\text { innovation }\end{array}$ & $\begin{array}{l}\text { It presents what unique features } \\
\text { and capabilities product-centric } \\
\text { companies should develop and } \\
\text { deploy to pursue service } \\
\text { innovation }\end{array}$ & Detailed & 10 \\
\hline
\end{tabular}


Literature analysis on product-service systems business model: a promising research field

Table 4. Continued...

\begin{tabular}{|c|c|c|c|c|}
\hline Publication & Main focus & Brief description & $\begin{array}{l}\text { Depth of } \\
\text { contents }\end{array}$ & $\begin{array}{c}\text { \# of } \\
\text { components }\end{array}$ \\
\hline Chiu et al. (2015) & $\begin{array}{c}\text { Digital } \\
\text { Products } \\
\text { Manufacturer }\end{array}$ & $\begin{array}{l}\text { It analyses the literature and } \\
\text { presents } 6 \text { elements needed to } \\
\text { develop a PSS business model }\end{array}$ & Detailed & 6 \\
\hline $\begin{array}{l}\text { Gelbmann and } \\
\text { Hammerl (2015) }\end{array}$ & PSS for reuse & $\begin{array}{l}\text { It presents a framework for PSS for } \\
\text { reuse (ECO-WISE) aligned with TBL } \\
\text { highlighting the importance of } \\
\text { integration with stakeholders }\end{array}$ & Detailed & 6 \\
\hline Reim et al. (2015) & PSS & $\begin{array}{l}\text { It describes each type of PSS } \\
\text { (based on Tukker, 2004) linked } \\
\text { to five operational-level tactics } \\
\text { and practices related to the } \\
\text { implementation of PSS business } \\
\text { models }\end{array}$ & $\begin{array}{l}\text { Detailed } \\
\text { (2 levels) }\end{array}$ & $13^{*}$ \\
\hline $\begin{array}{l}\text { Bocken and Short } \\
\qquad(2016)\end{array}$ & $\begin{array}{l}\text { Sustainable } \\
\text { innovation }\end{array}$ & $\begin{array}{l}\text { It depicts a framework for } \\
\text { business model innovation for } \\
\text { sustainability }\end{array}$ & $\begin{array}{c}\text { General, } \\
\text { exemplified }\end{array}$ & 11 \\
\hline $\begin{array}{l}\text { Kanda et al. } \\
\qquad(2016)\end{array}$ & $\begin{array}{l}\text { Large scaled } \\
\text { environment } \\
\text { al technology } \\
\text { systems }\end{array}$ & $\begin{array}{l}\text { It proposes the components to } \\
\text { consider when developing large- } \\
\text { scale environmental technology } \\
\text { systems BM (e.g., renewable } \\
\text { energy systems) }\end{array}$ & Detailed & 6 \\
\hline $\begin{array}{c}\text { Tran and Park } \\
\text { (2016) }\end{array}$ & $\begin{array}{l}\text { Co-creation } \\
\text { for PSS } \\
\text { redesign }\end{array}$ & $\begin{array}{l}\text { It proposes a co-creation } \\
\text { framework, for designers to } \\
\text { effectively design PSS in terms of } \\
\text { users' perception of PSS value, } \\
\text { design quality and evaluation }\end{array}$ & $\begin{array}{l}\text { Detailed } \\
\text { and } \\
\text { exemplified }\end{array}$ & 7 \\
\hline $\begin{array}{l}\text { Zancul et al. } \\
\qquad(2016)\end{array}$ & IPSS & $\begin{array}{l}\text { It highlights the role of } \\
\text { technology and Internet of } \\
\text { Things (IoT) in PSS business } \\
\text { models, based on part the } \\
\text { components of BMC }\end{array}$ & $\begin{array}{l}\text { Detailed } \\
\text { and } \\
\text { exemplified }\end{array}$ & 7 \\
\hline $\begin{array}{l}\text { Adrodegari and } \\
\text { Saccani (2017) }\end{array}$ & $\begin{array}{l}\text { Service } \\
\text { transformatio } \\
\mathrm{n} \text { of industrial } \\
\text { firms }\end{array}$ & $\begin{array}{l}\text { It analyzes the business model } \\
\text { literature and proposes a structure } \\
\text { for the transformation of industrial } \\
\text { companies, based on BMC }\end{array}$ & Detailed & 8 \\
\hline $\begin{array}{l}\text { Adrodegari et al. } \\
\qquad(2017)\end{array}$ & IPSS & $\begin{array}{l}\text { It describes the relevance of } \\
\text { each of the BMC components to } \\
\text { PSS and subdivides the core } \\
\text { components highlighted by the } \\
\text { template into topics }\end{array}$ & $\begin{array}{l}\text { Detailed } \\
\text { and } \\
\text { exemplified }\end{array}$ & 8 \\
\hline $\begin{array}{l}\text { Fjeldstad and } \\
\text { Snow (2018) }\end{array}$ & $\begin{array}{l}\text { Business } \\
\text { model and } \\
\text { organization } \\
\text { structure }\end{array}$ & $\begin{array}{l}\text { It points out that each of the } \\
\text { elements of a business model is } \\
\text { affected by the configuration of } \\
\text { the company's value, connecting } \\
\text { the business model to the } \\
\text { organization design }\end{array}$ & Detailed & 8 \\
\hline $\begin{array}{l}\text { Petrulaitiene et al. } \\
\qquad(2018)\end{array}$ & Servitization & $\begin{array}{l}\text { Describes the elements in the } \\
\text { workplace servitization process } \\
\text { with a focus on greater flexibility } \\
\text { and experience orientation }\end{array}$ & Detailed & 5 \\
\hline $\begin{array}{l}\text { Salomon et al. } \\
\qquad(2019)\end{array}$ & $\begin{array}{l}\text { PSS in } \\
\text { aerospace } \\
\text { industry }\end{array}$ & $\begin{array}{l}\text { Prioritize the most important } \\
\text { elements of the BM using a } \\
\text { multi-criteria method }\end{array}$ & $\begin{array}{l}\text { General (in } \\
2 \text { levels) }\end{array}$ & $20 *$ \\
\hline
\end{tabular}

Note: *refer to the $2^{\text {nd }}$ level of components. 
As can be seen in Table 4, although many publications focus on PSS business model, only a few of them develop their structure specifically for PSS.

Although the main focus is on internet-related business, Osterwalder and Pigneur (2010) describe the market introduction process of Car2Go (car-sharing system - a classic example of PSS) as an example of business model innovation that complements Daimler's core business model. It is worth emphasizing that BMC is the most used structure in the publications analyzed, although it is not from a peer-reviewed journal. In this sense, the components described in the selected publications were compared as the Canvas model components of Osterwalder and Pigneur (2010). Table 5 presents studies addressing business model structures that can be applied to different types of organizations. In this sense, we excluded those studies developed for specific contexts such as aerospace industry (Salomon et al., 2019), environmental technology systems (Kanda et al., 2016), and workplace servitization (Petrulaitiene et al. 2018).

Table 5. Comparison among business model components presented by the literature.

\begin{tabular}{|c|c|c|c|c|c|c|c|c|c|c|}
\hline \multirow{2}{*}{ Publication } & \multicolumn{9}{|c|}{ Business model components (Figure 1*) } & \multirow{2}{*}{$\begin{array}{l}\text { Other components } \\
\text { pointed by the } \\
\text { publications }\end{array}$} \\
\hline & 1 & 2 & 3 & 4 & 5 & 6 & 7 & 8 & 9 & \\
\hline \multirow{4}{*}{$\begin{array}{l}\text { Meier et al. } \\
\text { (2010); Meier et } \\
\text { al. (2011) }\end{array}$} & & & & & & & & & & - Customer value \\
\hline & & & & & & & & & & $\begin{array}{c}\text { - Service delivery } \\
\text { model }\end{array}$ \\
\hline & & & & & & & & & & . Objects/resources \\
\hline & & & & & & & & & & - Processes \\
\hline \multirow{3}{*}{$\begin{array}{l}\text { Boons and } \\
\text { Lüdeke-Freund } \\
\text { (2013) }\end{array}$} & & \multirow{3}{*}{$\checkmark$} & & & & & & & & - Customer interface \\
\hline & & & & & & & & & & - Supply chain \\
\hline & & & & & & & & & & $\begin{array}{c}\text { - Financial model - } \\
\text { similar to (5) }\end{array}$ \\
\hline \multirow{2}{*}{$\begin{array}{c}\text { Bocken et al. } \\
\text { (2014) }\end{array}$} & \multirow{2}{*}{$\checkmark$} & & \multirow{2}{*}{$\checkmark$} & \multirow{2}{*}{$\checkmark$} & \multirow{2}{*}{$\checkmark$} & \multirow{2}{*}{$\checkmark$} & \multirow{2}{*}{$\checkmark$} & \multirow{2}{*}{$\checkmark$} & \multirow{2}{*}{$\checkmark$} & $\cdot$ Technology \\
\hline & & & & & & & & & & - Product/service \\
\hline \multirow{3}{*}{$\begin{array}{l}\text { Gaiardelli et al. } \\
\qquad(2014)\end{array}$} & & \multirow{3}{*}{$\checkmark$} & & & & & & & & $\begin{array}{l}\text { Infrastructure and } \\
\text { network }\end{array}$ \\
\hline & & & & & & & & & & $\begin{array}{c}\text { - Relationship } \\
\text { capital }\end{array}$ \\
\hline & & & & & & & & & & $\begin{array}{c}\text { - Sustainable } \\
\text { aspects }\end{array}$ \\
\hline \multirow{8}{*}{$\begin{array}{l}\text { Kindström and } \\
\text { Kowalkowski } \\
\text { (2014) }\end{array}$} & & & & & & & & & & - Strategy \\
\hline & & & & & & & & & & - Structure \\
\hline & & & & & & & & & & - Culture \\
\hline & & & & & & & & & & . Offer \\
\hline & & & & $\checkmark$ & $\checkmark$ & & & & & - Sales process \\
\hline & & & & & & & & & & - Delivery process \\
\hline & & & & & & & & & & $\begin{array}{l}\text { Development } \\
\text { process }\end{array}$ \\
\hline & & & & & & & & & & - Value network \\
\hline \multirow{6}{*}{$\begin{array}{l}\text { Chiu et al. } \\
\text { (2015) }\end{array}$} & & & & & & & & & & $\begin{array}{l}\text { Product/Service and } \\
\text { Core Competence } \\
\text { Identification }\end{array}$ \\
\hline & & & & & & & & & & $\begin{array}{c}\cdot \text { Target Customer } \\
\text { Searching }\end{array}$ \\
\hline & & & & & & & & & & - Market Analysis \\
\hline & & & & & & & & & & $\begin{array}{l}\text { - Value Chain } \\
\text { Construction }\end{array}$ \\
\hline & & & & & & & & & & $\begin{array}{c}\text { - Cost and Revenue } \\
\text { Estimation }\end{array}$ \\
\hline & & & & & & & & & & $\begin{array}{l}\text { - Business Model } \\
\text { Transformation }\end{array}$ \\
\hline
\end{tabular}


Table 5. Continued...

\begin{tabular}{|c|c|c|c|c|c|c|c|c|c|c|}
\hline \multirow{2}{*}{ Publication } & \multicolumn{9}{|c|}{ Business model components (Figure 1*) $^{*}$} & \multirow{2}{*}{$\begin{array}{l}\text { Other components } \\
\text { pointed by the } \\
\text { publications }\end{array}$} \\
\hline & 1 & 2 & 3 & 4 & 5 & 6 & 7 & 8 & 9 & \\
\hline \multirow{4}{*}{$\begin{array}{l}\text { Gelbmann and } \\
\text { Hammerl (2015) }\end{array}$} & & \multirow{4}{*}{$\checkmark$} & & & & & \multirow{4}{*}{$\checkmark$} & & & - Stakeholders \\
\hline & & & & & & & & & & - Key features \\
\hline & & & & & & & & & & $\begin{array}{l}\text { Relationship and } \\
\text { partnerships }\end{array}$ \\
\hline & & & & & & & & & & $\begin{array}{c}\text { · Financial } \\
\text { implications similar } \\
\text { to }(5) \\
\end{array}$ \\
\hline \multirow{5}{*}{$\begin{array}{l}\text { Reim et al. } \\
\text { (2015) }\end{array}$} & & & & & & & & & & - Sustainability \\
\hline & & & & & & & & & & - Marketing \\
\hline & & & & & & & & & & - Contracts \\
\hline & & & & & & & & & & $\begin{array}{l}\text { - Product and } \\
\text { service design }\end{array}$ \\
\hline & & & & & & & & & & - Networks \\
\hline \multirow{5}{*}{$\begin{array}{l}\text { Bocken and } \\
\text { Short (2016) }\end{array}$} & \multirow{5}{*}{$\checkmark$} & & \multirow{5}{*}{$\checkmark$} & & \multirow{5}{*}{$\checkmark$} & \multirow{5}{*}{$\checkmark$} & \multirow{5}{*}{$\checkmark$} & \multirow{5}{*}{$\checkmark$} & \multirow{5}{*}{$\checkmark$} & - Product/service \\
\hline & & & & & & & & & & $\begin{array}{c}\text {. Value for } \\
\text { customers, society } \\
\text { and environment }\end{array}$ \\
\hline & & & & & & & & & & $\begin{array}{l}\text { Technology and } \\
\text { product features }\end{array}$ \\
\hline & & & & & & & & & & $\begin{array}{l}\text { - Value capture for } \\
\text { key actors }\end{array}$ \\
\hline & & & & & & & & & & $\begin{array}{c}\cdot \text { Growth } \\
\text { strategy/ethos }\end{array}$ \\
\hline \multirow{6}{*}{$\begin{array}{c}\text { Tran and Park } \\
\text { (2016) }\end{array}$} & & \multirow{6}{*}{$\checkmark$} & & & & & & & & - Product \\
\hline & & & & & & & & & & - Service \\
\hline & & & & & & & & & & - Process \\
\hline & & & & & & & & & & - Parameters \\
\hline & & & & & & & & & & - Network \\
\hline & & & & & & & & & & - Stakeholders \\
\hline $\begin{array}{c}\text { Zancul et al. } \\
\text { (2016) }\end{array}$ & $\checkmark$ & $\checkmark$ & & $\checkmark$ & $\checkmark$ & $\checkmark$ & $\sqrt{ }^{* *}$ & $\sqrt{ }^{* *}$ & $\checkmark$ & $\begin{array}{l}\text { Not indicated by } \\
\text { publication }\end{array}$ \\
\hline \multirow{2}{*}{$\begin{array}{l}\text { Adrodegari and } \\
\text { Saccani (2017) }\end{array}$} & \multirow{2}{*}{$\checkmark$} & \multirow{2}{*}{$\checkmark$} & & & \multirow{2}{*}{$\checkmark$} & \multirow{2}{*}{$\checkmark$} & \multirow{2}{*}{$\checkmark$} & & \multirow{2}{*}{$\checkmark$} & - Strategy \\
\hline & & & & & & & & & & - Network \\
\hline $\begin{array}{c}\text { Adrodegari et al. } \\
(2017)\end{array}$ & $\checkmark$ & $\checkmark$ & $\checkmark$ & & $\checkmark$ & $\checkmark$ & $\checkmark$ & $\checkmark$ & $\checkmark$ & $\begin{array}{c}\text { Not indicated by } \\
\text { publication }\end{array}$ \\
\hline \multirow{3}{*}{$\begin{array}{l}\text { Fjeldstad and } \\
\text { Snow (2018) }\end{array}$} & \multirow{3}{*}{$\checkmark$} & \multirow{3}{*}{$\checkmark$} & & & \multirow{3}{*}{$\checkmark$} & & & & & $\begin{array}{c}\text { Product/service } \\
\text { offers }\end{array}$ \\
\hline & & & & & & $\checkmark$ & $\checkmark$ & & & . Economy \\
\hline & & & & & & & & & & $\begin{array}{l}\cdot \text { Protection } \\
\text { mechanisms }\end{array}$ \\
\hline
\end{tabular}

Source: Constructed based on content of publications. Note: * The numbers refer to the components shown in Figure 1: (1) - Customer segments; (2) - Value Proposition; (3) - Channels; (4) - Customer Relationships; (5) - Revenue streams; (6) - Key resources; (7) - Key activities; (8) - Key partners; and (9) - Cost structure; **(7) and (8) were considered only one component

Based on the components' analysis, those components proposed by Osterwalder and Pigneur (2010) are present in a large part of the models described by other authors (e.g., Adrodegari et al., 2017; França et al., 2017; Fjeldstad and Snow, 2018). Other subsequent publications apply the BMC by Osterwalder and Pigneur (2010) for the development of PSS solutions (e.g., Barquet et al., 2013; França et al., 2017), part of the components (e.g., Gelbmann and Hammerl, 2015; Zancul et al., 2016; Adrodegari et al., 2017), or add new components (e.g., Reim et al., 2015; Fjeldstad and Snow, 2018).

Table 6 organizes the 14 components identified as critical to PSS business models value proposition, value creation, delivery, and value capture. 
Table 6. Contributions of business models from the literature.

\begin{tabular}{|c|c|}
\hline $\begin{array}{l}\text { Business model } \\
\text { components }\end{array}$ & Description \\
\hline Value proposition & $\begin{array}{l}\text { Describe the assumptions of its purposes for consumers, differentiating } \\
\text { them from competitors and supporting their activities and use of resources } \\
\text { (Bocken et al., 2014) }\end{array}$ \\
\hline Customer segments & $\begin{array}{c}\text { Group of people or organizations that the company intends to offer its } \\
\text { solution (Osterwalder and Pigneur, 2010) }\end{array}$ \\
\hline Customer jobs & $\begin{array}{l}\text { Functions and/or situations for which the consumer will use the solution } \\
\text { (Osterwalder et al., 2015) }\end{array}$ \\
\hline $\begin{array}{c}\text { Customer } \\
\text { pains/problems }\end{array}$ & $\begin{array}{l}\text { Describe the problems that block the customer from performing their tasks } \\
\text { (Osterwalder et al., 2015) }\end{array}$ \\
\hline $\begin{array}{l}\text { Customer } \\
\text { gains/benefits }\end{array}$ & $\begin{array}{l}\text { Represent the benefit for which the customer is willing to pay } \\
\text { (Gaiardelli et al., 2014) }\end{array}$ \\
\hline $\begin{array}{l}\text { Customer } \\
\text { relationships }\end{array}$ & $\begin{array}{l}\text { Describe how the company establish direct contact with the consumer } \\
\text { (Osterwalder and Pigneur, 2010) }\end{array}$ \\
\hline \multirow{2}{*}{ Key resources } & $\begin{array}{l}\text { The most important internal and external resources required to operate the } \\
\text { business model, e.g., human, financial, and technology (Adrodegari and } \\
\text { Saccani, 2017) }\end{array}$ \\
\hline & $\begin{array}{l}\text { Maximizing resource usage throughout the PSS life cycle (Vasantha et al., } \\
\text { 2012, Yang et al., 2017) }\end{array}$ \\
\hline \multirow{2}{*}{ Key activities } & $\begin{array}{l}\text { The most important activities to deliver the value proposition (Adrodegari } \\
\text { and Saccani, 2017) }\end{array}$ \\
\hline & $\begin{array}{l}\text { Focus on activities that allow product longevity and system's eco-efficiency } \\
\text { at PSS (Moro et al., 2021) }\end{array}$ \\
\hline Key partners & $\begin{array}{c}\text { Activities and resources that go beyond company boundaries, including } \\
\text { partnerships between concerned parties such as producers, resellers, } \\
\text { customers, and 'end-of-life products administrators' with connected } \\
\text { economic interests (Morelli, 2006) }\end{array}$ \\
\hline \multirow{3}{*}{$\begin{array}{l}\text { Distribution } \\
\text { channels/Processes }\end{array}$} & $\begin{array}{l}\text { Description of how the company reaches the customer segment to deliver } \\
\text { its value proposition (Osterwalder and Pigneur, 2010) }\end{array}$ \\
\hline & $\begin{array}{l}\text { Description of how a PSS is served to the customer, considering the serial } \\
\text { and parallel activities that occur for the PSS provision (Tran and Park, 2016) }\end{array}$ \\
\hline & $\begin{array}{l}\text { Seek to emphasize value delivered, improving system efficiency (Moro et al., } \\
\text { 2021) }\end{array}$ \\
\hline \multirow{2}{*}{ Revenue streams } & $\begin{array}{c}\text { Represent how the company makes money from the target customer } \\
\text { segment (Osterwalder and Pigneur, 2010) }\end{array}$ \\
\hline & $\begin{array}{l}\text { In a PSS, costumers pay for the use of the service and/or for the work done } \\
\text { (Boons and Lüdeke-Freund, 2013) }\end{array}$ \\
\hline \multirow{4}{*}{ Cost structure } & $\begin{array}{l}\text { Describe all costs involved in the business model provision (Osterwalder } \\
\text { and Pigneur, 2010) }\end{array}$ \\
\hline & $\begin{array}{l}\text { The cost of owning the physical products is borne by the company and its } \\
\text { partners (Bocken et al., 2014) }\end{array}$ \\
\hline & $\begin{array}{l}\text { The company has responsibility for economic, environmental, and social } \\
\text { issues during and after the product use phase (Evans et al., 2017) }\end{array}$ \\
\hline & $\begin{array}{l}\text { In a PSS, to reduce cost, the focus should be on reducing resource use and } \\
\text { system effectiveness (Moro et al., 2021) }\end{array}$ \\
\hline \multirow[b]{2}{*}{ Indicators/Parameters } & Metrics of product and service features (Tran and Park, 2016) \\
\hline & $\begin{array}{c}\text { Indicators related to: customer responsiveness and acceptance; waste, } \\
\text { emissions, and pollution reducing; and product durability and maintenance } \\
\text { efficiency (Moro et al., 2021) }\end{array}$ \\
\hline \multirow[t]{2}{*}{ Value network } & $\begin{array}{l}\text { The infrastructure of PSS and its interactions of products, services, } \\
\text { customers, etc. (Tran and Park, 2016) }\end{array}$ \\
\hline & An integrated network of suppliers with clearly defined roles (Morelli, 2006) \\
\hline
\end{tabular}

By the analysis, other components were identified, such as technology (Bocken et al., 2014), sustainability (Reim et al., 2015), and economy (Fjeldstad and Snow, 2018). However, 
those components may be present in more than one of the components considered. Strategy, defined as a plan of action designed to achieve a specific goal (Adrodegari and Saccani, 2017), was not considered as a component, because it also refers to a broader concept.

\section{DISCUSSION}

Through the analysis of the main journals with publications, it seems evident that several areas approach the PSS as a business model, with an emphasis on sustainability-related journal sources. Nevertheless, the literature points out that there is still a lack of interconnection between fields and areas thematic (Annarelli et al., 2016). In addition, the PSS integrates different agents and life cycles, and only the solution (product + service) design cannot provide solutions according to customer needs (Tukker, 2015). Thus, the importance of understanding the market and aligning the PSS with operational issues is highlighted by analyzing PSS business model recent publication's sources. In this sense, the study of the PSS as a business model presents itself as a possibility for a more general analysis of the PSS since it integrates several components, which, in addition to the solution, present its integration with other stakeholders (customers and partners).

As showed in Table 6, 14 components related to the functioning of the business model were identified through content analysis. To some extent, some of those components are common in most of the structures presented in Table 5 (e.g., value proposition, key partners, and so on). Value proposition is found as a component and a mechanism in the (broader sense) in the publications and, therefore, its concept deserves a deeper analysis, which is one of this work recommendation.

Despite following a logical sequence, the process of structuring the PSS business model should be cyclical and iterative and not necessarily sequential and linear (Tukker, 2015). A PSS business model allows the collection of data regarding the product/service during its use and product monitoring (Zancul et al., 2016), facilitating the provision of information for changes, redesign of products, and information on the scope of the development of services necessary to meet the future needs of customers (Parida et al., 2014). Finally, it is emphasized that the global economy is increasingly digital, networked, and knowledge-based, which requires companies to reconsider their business models constantly and, if necessary, modify them to adapt to changing conditions (Fjeldstad and Snow, 2018). Therefore, there must be integration and exchange of information between stakeholders so that the product-service system business model includes all those involved in the value network, in a sustainable way.

\section{CONCLUSIONS}

The business model is still a relatively recent concept in addition to the fact that productservice system interest has increased in recent years. So, applying the business model concept to structure a PSS can favor its understanding and facilitate the development and subsequent implementation activities. Based on a literature analysis, 14 components were identified to be taken into account when structuring a business model. These components were organized in this work in mechanisms of value proposition, value creation, value delivery, and value capture. Indeed, a value-centric vision is essential for the business model to meet customers' needs and the interests of the PSS value network members sustainably. These PSS business model concepts related to sustainability and value mechanisms were then discussed in this work to achieve a better understanding of this research topic. Nevertheless, some valuerelated concepts need an in-deeper analysis, such as 'value proposition' and 'value network'. This is recommended for further research.

As a limitation of this work, the analysis covered only the researchers' point of view on product-service systems. When considering PSS as a business model, it is also essential to consider the literature on servitization since it refers to creating revenue streams for service organizations. Thus, as another work opportunity would be to include search terms related to servitization, aiming at broadening the scope of the current literature review. Moreover, 
another research opportunity could be a bibliometric analysis, for instance by using software such as VOSviewer ${ }^{\mathrm{TM}}$ which may also reveal relevant insights about the literature's evolution. Interdisciplinary studies (e.g., marketing) to analyze the 'value' concept are also needed to enhance PSS business model knowledge. Furthermore, it would be also relevant to analyze business model literature and those concepts to provide a better understanding of how they could be effectively applied in a product-service system.

\section{ACKNOWLEDGEMENTS}

The authors appreciate the support of Coordination for the Improvement of Higher Level Education Personnel (CAPES) and National Council for Scientific and Technological Development (CNPq) - doctorate grant [140460/2016-0] and financial support [428946/20186]. This manuscript is an expanded and enhanced version from the one (in Portuguese) presented in $12^{\circ}$ Congresso Brasileiro de Inovação e Gestão de Desenvolvimento do Produto CBGDP 2019, organized by Institute for Product Development Management (IGDP) in Brazil. Finally, the authors appreciate the assistance of the editors as well as the reviewers' comments that surely helped to enhance the manuscript.

\section{REFERENCES}

Adams, R.J., Smart, P. and Huff, A.S. (2017), "Shades of grey: guidelines for working with the grey literature in systematic reviews for management and organizational studies", International Journal of Management Reviews, Vol. 19, No. 4, pp. 432-54. http://dx.doi.org/10.1111/ijmr.12102.

Adrodegari, F. and Saccani, N. (2017), "Business models for the service transformation of industrial firms", Service Industries Journal, Vol. 37, No. 1, pp. 57-83. http://dx.doi.org/10.1080/02642069.2017.1289514.

Adrodegari, F., Saccani, N., Kowalkowski, C. et al. (2017), "PSS business model conceptualization and application", Production Planning and Control, Vol. 28, No. 15, pp. 1251-63. http://dx.doi.org/10.1080/09537287.2017.1363924.

Annarelli, A., Battistella, C. and Nonino, F. (2016), "Product service system: a conceptual framework from a systematic review", Journal of Cleaner Production, Vol. 139, pp. 1011-32. http://dx.doi.org/10.1016/j.jclepro.2016.08.061.

Barquet, A.P.B., Oliveira, M.G., Amigo, C.R. et al. (2013), "Employing the business model concept to support the adoption of product-service systems (PSS)", Industrial Marketing Management, Vol. 42, No. 5, pp. 693-704. http://dx.doi.org/10.1016/j.indmarman.2013.05.003.

Beuren, F.H., Ferreira, M.G.G. and Cauchick Miguel, P.A. (2013), "Product-service systems: a literature review on integrated products and services", Journal of Cleaner Production, Vol. 47, pp. 222-31. http://dx.doi.org/10.1016/j.jclepro.2012.12.028.

Bocken, N.M. and Short, S.W. (2016), "Towards a sufficiency-driven business model: experiences and opportunities", Environmental Innovation and Societal Transitions, Vol. 18, pp. 41-61. http://dx.doi.org/10.1016/j.eist.2015.07.010.

Bocken, N.M., Short, S.W., Rana, P. et al. (2014), "A literature and practice review to develop sustainable business model archetypes", Journal of Cleaner Production, Vol. 65, pp. 42-56. http://dx.doi.org/10.1016/j.jclepro.2013.11.039.

Boons, F. and Lüdeke-Freund, F. (2013), "Business models for sustainable innovation: state-of-the-art and steps towards a research agenda", Journal of Cleaner Production, Vol. 45, pp. 9-19. http://dx.doi.org/10.1016/j.jclepro.2012.07.007.

Booth, A., Sutton, A. and Papaioannou, D. (2012), Systematic Approaches to a Successful Literature Review. Sage Publications Ltd., Thousand Oaks, CA.

Brambila-Macias, S.A., Sakao, T. and Kowalkowski, C. (2018), "Bridging the gap between engineering design and marketing: insights for research and practice in product/service system design", Design Science, Vol. 4, pp. e7. http://dx.doi.org/10.1017/dsj.2018.3.

Charro, A. and Schaefer, D. (2018), "Cloud Manufacturing as a new type of Product-Service System", International Journal of Computer Integrated Manufacturing, Vol. 31, No. 10, pp. 1018-33. http://dx.doi.org/10.1080/0951192X.2018.1493228. 
Chesbrough, H. and Rosenbloom, R.S. (2002), "The role of the business model in capturing value from innovation: evidence from Xerox Corporation's technology spin-off companies", Industrial and Corporate Change, Vol. 11, No. 3, pp. 529-55. http://dx.doi.org/10.1093/icc/11.3.529.

Chiu, M.C., Kuo, M.Y. and Kuo, T.C. (2015), "A Systematic methodology to develop business model of a product service system", International Journal of Industrial Engineering, Vol. 22, No. 3, pp. 369-81.

Clark, G., Kosoris, J., Hong, L.N. et al. (2009), "Design for sustainability: current trends in sustainable product design and development", Sustainability, Vol. 1, No. 3, pp. 409-24. http://dx.doi.org/10.3390/su1030409.

Estigarribia, J. (2020), "Carro por assinatura: Volkswagen lança serviço e promete preço competitivo", Exame, available at: https://exame.com/negocios/carro-por-assinatura-volkswagen-lanca-servico-epromete-preco-competitivo/ (accessed 17 April 2021).

Evans, S., Vladimirova, D., Holgado, M. et al. (2017), "Business model innovation for sustainability: towards a unified perspective for creation of sustainable business models", Business Strategy and the Environment, Vol. 26, No. 5, pp. 597-608. http://dx.doi.org/10.1002/bse.1939.

Fjeldstad, $\varnothing . D$. and Snow, C.C. (2018), "Business models and organization design", Long Range Planning, Vol. 51, No. 1, pp. 32-9. http://dx.doi.org/10.1016/j.Irp.2017.07.008.

França, C.L., Broman, G., Robert, K.H. et al. (2017), "An approach to business model innovation and design for strategic sustainable development", Journal of Cleaner Production, Vol. 140, pp. 155-66. http://dx.doi.org/10.1016/j.jclepro.2016.06.124.

Gaiardelli, P., Resta, B., Martinez, V. et al. (2014), "A classification model for product-service offerings", Journal of Cleaner Production, Vol. 66, pp. 507-19. http://dx.doi.org/10.1016/j.jclepro.2013.11.032.

Geissdoerfer, M., Morioka, S.N., Carvalho, M.M. et al. (2018), "Business models and supply chains for the circular economy", Journal of Cleaner Production, Vol. 190, pp. 712-21. http://dx.doi.org/10.1016/j.jclepro.2018.04.159.

Gelbmann, U. and Hammerl, B. (2015), "Integrative re-use systems as innovative business models for devising sustainable product-service-systems", Journal of Cleaner Production, Vol. 97, pp. 50-60. http://dx.doi.org/10.1016/j.jclepro.2014.01.104.

Gembarski, P.C. and Lachmayer, R. (2017), "Designing customer co-creation: business models and codesign activities", International Journal of Industrial Engineering and Management, Vol. 8, No. 3, pp. 12130. [IJIEM]

Gough, D., Oliver, S. and Thomas, J. (Eds.) (2012), An Introduction to Systematic Reviews, Sage Publications Ltd., Thousand Oaks, CA.

Kanda, W., Sakao, T. and Hjelm, O. (2016), "Components of business concepts for the diffusion of large scaled environmental technology systems", Journal of Cleaner Production, Vol. 128, pp. 156-67. http://dx.doi.org/10.1016/j.jclepro.2015.10.040.

Kindström, D. and Kowalkowski, C. (2014), "Service innovation in product-centric firms: A multidimensional business model perspective", Journal of Business and Industrial Marketing, Vol. 29, No. 2, pp. 96-111. http://dx.doi.org/10.1108/JBIM-08-2013-0165.

King, W.R. and He, J. (2005), "Understanding the role and methods of meta-analysis in IS research", Communications of the Association for Information Systems, Vol. 16, No. 1, pp. 32. http://dx.doi.org/10.17705/1CAIS.01632.

Kwon, M., Lee, J. and Hong, Y.S. (2019), "Product-service system business modelling methodology using morphological analysis", Sustainability, Vol. 11, No. 5, pp. 1376. http://dx.doi.org/10.3390/su11051376.

Mahut, F., Daaboul, J., Bricogne, M. et al. (2017), "Product-Service Systems for servitization of the automotive industry: a literature review", International Journal of Production Research, Vol. 55, No. 7, pp. 2102-20. http://dx.doi.org/10.1080/00207543.2016.1252864.

Majava, J. and Isoherranen, V. (2019), "Business model evolution of customer care services", Journal of Industrial Engineering and Management, Vol. 12, No. 1, pp. 1-12. http://dx.doi.org/10.3926/jiem.2725.

Meier, H., Roy, R. and Seliger, G. (2010), "Industrial product-service systems-IPS2", CIRP AnnalsManufacturing Technology, Vol. 59, No. 2, pp. 607-27. http://dx.doi.org/10.1016/j.cirp.2010.05.004. 
Meier, H., Völker, O. and Funke, B. (2011), "Industrial product-service systems-IPS 2", International Journal of Advanced Manufacturing Technology, Vol. 52, No. 9, pp. 1175-91. http://dx.doi.org/10.1007/s00170010-2764-6.

Monteiro, G. (2020), “Volkswagen lança programa de carros por assinatura no Brasil", Quatro Rodas, available at: https://quatrorodas.abril.com.br/noticias/volkswagen-lanca-programa-de-carros-porassinatura-no-brasil/ (accessed 17 April 2021).

Morelli, N. (2006), "Developing new product service systems (PSS): methodologies and operational tools", Journal of Cleaner Production, Vol. 14, No. 17, pp. 1495-501. http://dx.doi.org/10.1016/j.jclepro.2006.01.023.

Moro, S.R., Cauchick-Miguel, P.A. and Campos, L.M.S. (2021), "Product-service systems towards ecoeffective production patterns: a Lean-Green design approach from a literature review", Total Quality Management \& Business Excellence, Vol. 32, No. 9-10, pp. 1046-64. http://dx.doi.org/10.1080/14783363.2019.1655398.

Oliveira, M.G., Mendes, G.H.S., Albuquerque, A.A. et al. (2018), "Lessons learned from a successful industrial product service system business model: emphasis on financial aspects", Journal of Business and Industrial Marketing, Vol. 33, No. 3, pp. 365-76. http://dx.doi.org/10.1108/JBIM-07-2016-0147.

Osterwalder, A. (2004), The Business Model Ontology a Proposition in a Design Science Approach, Doctoral Dissertation, Faculté des Hautes Études Commerciales, Université de Lausanne, France.

Osterwalder, A. and Pigneur, Y. (2010), Business Model Generation: a Handbook for Visionaries, Game Changers, and Challengers, John Wiley \& Sons, Hoboken.

Osterwalder, A., Pigneur, Y. and Tucci, C.L. (2005), "Clarifying business models: Origins, present, and future of the concept", Communications of the Association for Information Systems, Vol. 16, No. 1, pp. 1. http://dx.doi.org/10.17705/1CAIS.01601.

Osterwalder, A., Pigneur, Y., Bernarda, G. et al. (2015), Value Proposition Design, John Wiley \& Sons, Hoboken.

Pallaro, E., Subramanian, N., Abdulrahman, M.D. et al. (2017), "Review of sustainable service-based business models in the Chinese truck sector", Sustainable Production and Consumption, Vol. 11, pp. 31-45. http://dx.doi.org/10.1016/j.spc.2016.07.003.

Parida, V., Sjödin, D.R., Wincent, J. et al. (2014), "Mastering the transition to product-service provision: Insights into business models, learning activities, and capabilities", Research Technology Management, Vol. 57, No. 3, pp. 44-52. http://dx.doi.org/10.5437/08956308X5703227.

Pawar, K.S., Beltagui, A. and Riedel, J.C.K.H. (2009), "The PSO triangle: designing product, service and organisation to create value", International Journal of Operations \& Production Management, Vol. 29, No. 5, pp. 468-93. http://dx.doi.org/10.1108/01443570910953595.

Petrulaitiene, V., Korba, P., Nenonen, S. et al. (2018), "From walls to experience-servitization of workplaces", Facilities, Vol. 36, No. 9/10, pp. 525-44. http://dx.doi.org/10.1108/F-07-2017-0072.

Pialot, O., Millet, D. and Bisiaux, J. (2017), "'Upgradable PSS": Clarifying a new concept of sustainable consumption/production based on upgradablility", Journal of Cleaner Production, Vol. 141, pp. 538-50. http://dx.doi.org/10.1016/j.jclepro.2016.08.161.

Reim, W., Parida, V. and Örtqvist, D. (2015), "Product-Service Systems (PSS) business models and tacticsa systematic literature review", Journal of Cleaner Production, Vol. 97, pp. 61-75. http://dx.doi.org/10.1016/j.jclepro.2014.07.003.

Richardson, J. (2008), "The business model: an integrative framework for strategy execution", Strategic Change, Vol. 17, No. 5-6, pp. 133-44. http://dx.doi.org/10.1002/jsc.821.

Salomon, M.F.B., Mello, C.H.P. and Salgado, E.G. (2019), "Prioritization of product-service business model elements at aerospace industry using analytical hierarchy process", Acta Scientiarum. Technology, Vol. 41, No. 1, e37934. http://dx.doi.org/10.4025/actascitechnol.v41i1.37934.

Scheepens, A.E., Vogtländer, J.G. and Brezet, J.C. (2016), "Two life cycle assessment (LCA) based methods to analyse and design complex (regional) circular economy systems. Case: Making water tourism more sustainable", Journal of Cleaner Production, Vol. 114, pp. 257-68. http://dx.doi.org/10.1016/j.jclepro.2015.05.075.

Seuring, S. and Gold, S. (2012), "Conducting content-analysis based literature reviews in supply chain management", Supply Chain Management, Vol. 17, No. 5, pp. 544-55. http://dx.doi.org/10.1108/13598541211258609. 
Short, S.W., Bocken, N.M., Barlow, C.Y. et al. (2014), "From refining sugar to growing tomatoes: Industrial ecology and business model evolution", Journal of Industrial Ecology, Vol. 18, No. 5, pp. 603-18. http://dx.doi.org/10.1111/jiec.12171.

Sousa-Zomer, T., Cantú, V. and Cauchick Miguel, P. (2016), "Product-service systems as sustainable alternatives to mobility: a comparative analysis of two bike-sharing systems", Brazilian Journal of Operations \& Production Management, Vol. 13, No. 3, pp. 264-75. http://dx.doi.org/10.14488/BJOPM.2016.v13.n3.a4.

Sousa-Zomer, T.T. and Cauchick-Miguel, P.A. (2019), "Exploring business model innovation for sustainability: an investigation of two product-service systems", Total Quality Management \& Business Excellence, Vol. 30, No. 5-6, pp. 594-612. http://dx.doi.org/10.1080/14783363.2017.1317588.

Sousa-Zomer, T.T., Magalhães, L., Zancul, E. et al. (2018), "Exploring the challenges for circular business implementation in manufacturing companies: An empirical investigation of a pay-per-use service provider", Resources, Conservation and Recycling, Vol. 135, pp. 3-13. http://dx.doi.org/10.1016/j.resconrec.2017.10.033.

Teece, D.J. (2010), "Business models, business strategy and innovation", Long Range Planning, Vol. 43, No. 2-3, pp. 172-94. http://dx.doi.org/10.1016/j.Irp.2009.07.003.

Tran, T. and Park, J.Y. (2016), "Development of a novel co-creative framework for redesigning product service systems", Sustainability, Vol. 8, No. 5, pp. 434. http://dx.doi.org/10.3390/su8050434.

Tukker, A. (2004), "Eight types of product-service system: eight ways to sustainability? Experiences from SusProNet", Business Strategy and the Environment, Vol. 13, No. 4, pp. 246-60. http://dx.doi.org/10.1002/bse.414.

Tukker, A. (2015), "Product services for a resource-efficient and circular economy-a review", Journal of Cleaner Production, Vol. 97, pp. 76-91. http://dx.doi.org/10.1016/j.jclepro.2013.11.049.

Van Halen, C., Vezzoli, C. and Wimmer, R. (2005), Methodology for Product Service System Innovation: How to Develop Clean, Clever and Competitive Strategies in Companies, Uitgeverij Van Gorcum. Assen, Netherlands.

Vasantha, G.V.A., Roy, R., Lelah, A. et al. (2012), "A review of product-service systems design methodologies", Journal of Engineering Design, Vol. 23, No. 9, pp. 635-59. http://dx.doi.org/10.1080/09544828.2011.639712.

Volkswagen (2021), available at: https://www.vwsignanddrive.com.br/ (accessed 17 April 2021).

Yang, M., Evans, S., Vladimirova, D. et al. (2017), "Value uncaptured perspective for sustainable business model innovation", Journal of Cleaner Production, Vol. 140, pp. 1794-804. http://dx.doi.org/10.1016/j.jclepro.2016.07.102.

Zancul, E.S., Takey, S.M., Barquet, A.P.B. et al. (2016), "Business process support for loT based productservice systems (PSS)", Business Process Management Journal, Vol. 22, No. 2, pp. 305-23. http://dx.doi.org/10.1108/BPMJ-05-2015-0078.

Author contributions: S.R. Moro - Conceptualization, Writing - Original Draft, Data Collection \& Analysis, and Project Administration; P.A. Cauchick-Miguel - Writing - Review \& Editing, Supervision, Funding acquisition; G.H.S. Mendes - Writing - Review \& Editing. 